JAMP: Jurnal Adminitrasi dan Manajemen Pendidikan

Volume 3 Nomor 2 Juni 2020, Hal : 110-117

Tersedia Online di http://journal2.um.ac.id/index.php/jamp/

ISSN 2615-8574 (online)

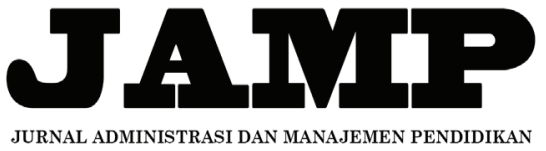

\title{
PENGARUH PENDIDIKAN KEWIRAUSAHAAN DAN PRAKTIK KERJA LAPANGAN UNIT BISNIS CENTER TERHADAP MINAT BERWIRAUSAHA
}

\author{
Dita Putri Cahyani \\ Bambang Budi Wiyono \\ Djum Djum Noor Benty \\ Universitas Negeri Malang. J1. Semarang 5 Malang 65145 \\ e-mail: dita.putricahyani@gmail.com.085806284716
}

\begin{abstract}
Abstrak: This study aims to find out: (1) variable description of (a) entrepreneurship education, (b) fieldwork practices of the Business Center units, and (c) entrepreneurial interests, (2) positive and significant influence of education entrepreneurship on entrepreneurial interest, (3) there is a positive and significant influence of fieldwork practices in the business center unit on entrepreneurial interest, (4) as well as a positive and significant influence on entrepreneurship education and business center fieldwork practices on entrepreneurial interest. This research uses a quantitative approach with descriptive analysis and hypothesis testing. The result of study: (1) showed that there was a significant positive effect between entrepreneurship education on the entrepreneurial interest of OTKP and XK grade students in Accounting, (2) There is a significant positive effect between the work practices of the business center business units, and (3) Simultaneously there is a positive and significant influence of entrepreneurship education and fieldwork practices in the business center units on entrepreneurial interest.
\end{abstract}

Keywords: entrepreneurship education, fieldwork practices, interest in entrepreneurship

\begin{abstract}
Abstrak: Penelitian ini bertujuan untuk mengetahui: (1) deskripsi variabel tentang (a) pendidikan kewirausahaan, (b) praktik kerja lapangan Unit Bisnis Center, dan (c) minat berwirausaha, (2) adanya pengaruh positif dan signifikan pendidikan kewirausahaan terhadap minat berwirausaha, (3) adanya pengaruh positif dan signifikan praktik kerja lapangan di unit bisnis center terhadap minat berwirausaha, (4) serta adanya pengaruh positif dan signifikan pendidikan kewirausahaan dan praktik kerja lapangan unit bisnis center terhadap minat berwirausaha. Penelitian ini menggunakan pendekatan kuantitatif dengan analisis deskriptif dan uji hipotesis. Hasil Penelitian menujukkan adanya pengaruh positif yang signifikan antara pendidikan kewirausahaan terhadap minat berwirausaha siswa kelas XI OTKP dan Akuntansi. Ada pengaruh positif yang signifikan antara praktik kerja lapangan unit bisnis center terhadap minat berwirausaha. Secara simultan terdapat pengaruh positif dan signifikan pendidikan kewirausahaan dan praktik kerja lapangan di unit bisnis center terhadap minat berwirausaha.
\end{abstract}

Kata kunci: pendidikan kewirausahaan, praktik kerja lapangan, minat berwirausaha

Perkembangan Era global sekarang ini menjadikan setiap orang dituntut untuk mengembangkan potensi diri dan mengasah ketrampilan diberbagai bidang. Persaingan untuk menjadi yang terbaik, menjadi pemicu orang-orang untuk mengembangkan apa yang mereka miliki. Hal ini juga berpengaruh kepada peserta didik tingkat menengah, terutama peserta didik SMK. Pada Era Revolusi Industri 4.0, generasi muda dituntut untuk selalu memberikan inovasi-inovasi terbaru yang dapat membawa perubahan bagi pengembangan kemajuan Negara Indonesia di berbagai sektor (pembangunan, perdagangan, dan kemajuan teknologi). Revolusi Industri telah mengubah hidup dan kerja manusia secara fundamental. 
Berbeda dengan Revolusi Industri sebelumnya, Revolusi Industri generasi ke-empat ini memiliki skala, ruang lingkup dan kompleksitas yang lebih luas. Kemajuan teknologi baru yang mengintegrasikan dunia fisik, digital dan biologis telah mempengaruhi semua disiplin ilmu, ekonomi, industri dan pemerintah.

Berbicara masalah Revolusi Industri 4.0 dan kaitannya dengan pendidikan tentu saja dunia pendidikan adalah hal yang utama dan sentral untuk mengikuti arus Revolusi Industri ini karena akan mencetak dan menghasilkan generasi-generasi berkualitas yang akan mengisi Revolusi Industri 4.0. Menurut Wijaya (2016:1) "Pendidikan tersebut tidak hanya mengandung aspek mengetahui entrepreneurship (to know), tetapi juga harus menjadi entrepreneur (to be) ". Pendidikan di era Revolusi Industri 4.0 berupa perubahan dari cara belajar, pola berpikir, serta cara bertindak para peserta didik dalam mengembangkan inovasi kreatif berbagai bidang. Salah satunya dengan adanya pendidikan kewirausahaan yang diajarkan di sekolah. Pendidikan entrepreneurship atau kewirausahaan telah mendapatkan perhatian pada lembagalembaga pendidikan di Indonesia. Pendidikan kewirausahaan yang saat ini begitu banyak bermunculan memberikan napas segar bagi metode dan kurikulum pendidikan kewirausahaan.

Sekolah di Indonesia terutama Sekolah Mengengah Kejuruan berupaya untuk mengasah dan meningkatkan kemampuan serta ketrampilan peserta didik dalam berbagai bidang, baik dari program kejuruan yang telah dipilih oleh peserta didik maupun bidang lainnya. Dalam hal ini pendidikan kewirausahaan, yang diharapkan mampu menumbuhkan minat berwirausaha peserta didik. Salah satu program yang ada di SMK Negeri 2 Kediri adanya Praktik Kerja Lapangan Unit Bisnis Center, yang dilakukan di lingkup dalam sekolah yang diharapkan mampu menumbuhkan minat berwirausaha peserta didik. Dengan adanya praktik kerja lapangan dan pendidikan kewirausahaan di sekolah yang bertujuan untuk menghasilkan generasi yang berkualitas dan berkompeten, dengan cara menumbuhkan minat berwirausaha peserta didik sejak masih dini (lingkungan sekolah). Berdasarkan latar belakang tersebut, maka penulis tertarik untuk mengadakan penelitian tentang pengaruh pendidikan kewirausahaan dan praktik kerja lapangan Unit Bisnis Center terhadap minta berwirausaha pada Kelas XI Jurusan OTKP dan Akuntansi SMK Negeri 2 Kediri

\section{METODE}

Penelitian ini menggunakan metode pendekatan kuantitatif dengan meggunakan analisis deskripstif (analisis regresi) dan uji hipotesis. Populasi yang digunakan oleh penulis merupakan peserta didik kelas XI jurusan Otomatisasi Tata Kelola Perkantoran (OTKP) dan Akuntansi sejumlah 321. Untuk sampel yang digunakan untuk pengambilan data sejumlah 214 peserta didik, terdiri dari empat (4) kelas untuk kelas XI OTKP dan dua (2) kelas XI Akuntansi.

Teknik pengumpulan yang digunakan oleh penulis merupakan angket atau kuisioner. Angket yang digunakan oleh penulis terdiri dari 48 pernyataan (11 pernyataan untuk variabel pendidikan kewirausahaan; 15 untuk variabel praktik kerja lapangan Unit Bisnis Center; dan 22 pernyataan untuk variabel minat berwirausaha). Angket penelitian sebelum digunakan harus melalui Uji Expert; uji validitas dan reliabilitas. Data yang digunakan penulis untuk penelitian diperoleh dari penyebaran angket atau kuisioner secara langsung pada sampel yang digunakan penulis (214 peserta didik) di SMK Negeri 2 Kediri.

Analisis data yang digunakan oleh penulis menggunakan analisis data deskriptif. Menurut Sugiyono (2016:147) "mengartikan bahwa statistik yang digunakan untuk menganalisis data dengan cara mendeskripsikan atau menggambarkan data yang telah terkumpul sebagaimana adanya tanpa bermaksud membuat kesimpulan yang berlaku untuk umum. Data yang digunakan dalam sebuah penelitian harus menggambarkan keseluruhan rumusan masalah yang ingin diketahui dan dikemukakan oleh penulis. Data yang telah diambil kemudian diolah, dianalisis dan diproses untuk mendapatkan hasil kemudian hasil analisis data dijabarkan di pembahasan dengan menggunakan teori yang mendukung dan penelitian terdahulu. 


\section{HASIL}

\section{Distribusi Variabel Pendidikan Kewirausahaan}

Pendidikan kewirausahaan terdiri dari dua sub variabel yaitu peningkatan potensi peserta didik dengan indikator (1) ketrampilan berwirausaha, (2) pengembangan aspek kepribadian peserta didik, dan (3)kemampuan berinovasi. Serta pembelajaran kewirausahaan berdasarkan kurikulum sekolah dengan indikator pengetahuan kewirausahaan. Pendidikan kewirausahaan terdiri dari 11 item pernyataan. Untuk mengukur indikator dapat menggunakan skala likert dengan rentang $1-4$ sesuai dengan alternatif pernyataan pada instrumen penelitian. Adapun distribusi jawaban responden mengenai pendidikan kewirausahaan dapat dilihat pada tabel dibawah ini

Tabel 1 Jawaban Responden Variabel Pendidikan Kewirausahaan

\begin{tabular}{|c|c|c|c|c|c|c|c|c|c|}
\hline \multirow{3}{*}{ Item } & \multicolumn{8}{|c|}{ Skor } & \multirow{3}{*}{ Rata - rata } \\
\hline & \multicolumn{2}{|c|}{4} & \multicolumn{2}{|c|}{3} & \multicolumn{2}{|c|}{2} & \multicolumn{2}{|c|}{1} & \\
\hline & f & $\%$ & f & $\%$ & f & $\%$ & f & $\%$ & \\
\hline item1 & 47 & 22 & 162 & 75,7 & 5 & 2,3 & 0 & $\mathbf{0}$ & 3,20 \\
\hline item2 & 97 & 45,3 & 113 & 52,8 & 4 & 1,9 & $\mathbf{0}$ & $\mathbf{0}$ & 3,43 \\
\hline item3 & 59 & 27,6 & 144 & 67,3 & 11 & 5,1 & $\mathbf{0}$ & $\mathbf{0}$ & 3,22 \\
\hline item4 & 97 & 45,3 & 111 & 51,9 & 6 & 2,8 & $\mathbf{0}$ & $\mathbf{0}$ & 3,43 \\
\hline item5 & 90 & 42,1 & 119 & 55,6 & 5 & 2,3 & $\mathbf{0}$ & $\mathbf{0}$ & 3,40 \\
\hline item6 & 74 & 34,6 & 136 & 63,6 & 4 & 1,9 & 0 & $\mathbf{0}$ & 3,33 \\
\hline item7 & 89 & 41,6 & 115 & 53,7 & 10 & 4,7 & 0 & $\mathbf{0}$ & 3,37 \\
\hline item8 & 67 & 31,3 & 143 & 66,8 & 4 & 1,9 & $\mathbf{0}$ & $\mathbf{0}$ & 3,29 \\
\hline item 9 & 93 & 43,5 & 119 & 55,6 & 2 & 9 & $\mathbf{0}$ & $\mathbf{0}$ & 3,43 \\
\hline item 10 & 35 & 16,4 & 150 & 70,1 & 29 & 13,6 & $\mathbf{0}$ & $\mathbf{0}$ & 3,03 \\
\hline item11 & 14 & 6,5 & 134 & 62,6 & 65 & 30,4 & 1 & 5 & 2,75 \\
\hline \multicolumn{3}{|c|}{ Rata -rata } & & & & & & & 3,26 \\
\hline
\end{tabular}

Adapun hasil distribusi variabel pendidikan kewirausahaan tergolong baik dengan rata- rata skor jawaban dengan nilai mean $=3,26$. Hal ini menunjukkan bahwa pendidikan kewirausahaan yang diajarkan si sekolah sangat mempengaruhi peserta didik untuk mengembangkan kompetensi dan potensi diri dalam dunia kewirausahaan.

\section{Distribusi Variabel Praktik Kerja Lapangan Unit Bisnis Center}

Praktik Kerja Lapangan Unit Bisnis Center terdiri sub variabel aspek yang dinilai dalam PKL menurut pedoman PKL Kurikulum 2013 dengan indikator: (1) kedisiplinan, (2) kejujuran, dan (3) menjalankan seluruh kegiatan di tempat PKL. Praktik Kerja Lapangan Unit Bisnis Center terdiri dari 15 item pernyataan. Untuk mengukur indikator dapat menggunakan skala likert dengan rentang $1-4$ sesuai dengan alternatif pernyataan pada instrumen penelitian.

Adapun distribusi jawaban responden mengenai pendidikan kewirausahaan dapat dilihat pada tabel dibawah ini.

Tabel 2 Jawaban Responden Variabel Praktik Kerja Lapangan Unit Bisnis Center

\begin{tabular}{|c|c|c|c|c|c|c|c|c|c|}
\hline \multirow{3}{*}{ Item } & \multicolumn{8}{|c|}{ Skor } & \multirow{3}{*}{ Rata - rata } \\
\hline & \multicolumn{2}{|c|}{4} & \multicolumn{2}{|c|}{3} & \multicolumn{2}{|c|}{2} & \multicolumn{2}{|c|}{1} & \\
\hline & f & $\%$ & f & $\%$ & f & $\%$ & f & $\%$ & \\
\hline item12 & 93 & 43,5 & 119 & 55,6 & 2 & 9 & 0 & 0 & 3,43 \\
\hline item13 & 74 & 34,6 & 134 & 62,6 & 5 & 2,3 & 1 & 5 & 3,31 \\
\hline item 14 & 85 & 39,7 & 126 & 58,9 & 2 & 9 & 1 & 5 & 3,38 \\
\hline item 15 & 79 & 36,9 & 131 & 61,2 & 3 & 1,4 & 1 & 5 & 3,35 \\
\hline item 16 & 101 & 47,2 & 113 & 52,8 & $\mathbf{0}$ & 0 & $\mathbf{0}$ & $\mathbf{0}$ & 3,47 \\
\hline
\end{tabular}




\begin{tabular}{|c|c|c|c|c|c|c|c|c|c|}
\hline \multirow{3}{*}{ Item } & \multicolumn{8}{|c|}{ Skor } & \multirow{3}{*}{ Rata - rata } \\
\hline & \multicolumn{2}{|c|}{4} & \multicolumn{2}{|c|}{3} & \multicolumn{2}{|c|}{2} & \multicolumn{2}{|c|}{1} & \\
\hline & f & $\%$ & f & $\%$ & f & $\%$ & f & $\%$ & \\
\hline item17 & 108 & $\mathbf{5 0 , 5}$ & 105 & 49,1 & 0 & 0 & 1 & 5 & 3,50 \\
\hline item18 & 45 & 21,0 & 147 & 68,7 & 22 & 10,3 & $\mathbf{0}$ & 0 & 3,11 \\
\hline item19 & 73 & 34,1 & 140 & 65,4 & 1 & 5 & 0 & 0 & 3,34 \\
\hline item20 & 18 & 8,4 & 135 & 63,1 & 58 & 27,1 & 3 & 1,4 & 2,79 \\
\hline item21 & 39 & 18,2 & 138 & 64,5 & 36 & 16,8 & 1 & 5 & 3,00 \\
\hline item22 & 69 & 32,2 & 144 & 67,3 & 1 & 5 & 0 & 0 & 3,32 \\
\hline item23 & 71 & 33,2 & 142 & 66,4 & 1 & 5 & $\mathbf{0}$ & 0 & 3,33 \\
\hline item24 & 28 & 13,1 & 142 & 66,4 & 43 & 20,1 & 1 & 5 & 2,92 \\
\hline item 25 & 48 & 22,4 & 150 & 70,1 & 16 & 7,5 & $\mathbf{0}$ & 0 & 3,15 \\
\hline item26 & 34 & 15,9 & 140 & 65,4 & 37 & 17,3 & 3 & 1,4 & 2,96 \\
\hline \multicolumn{3}{|c|}{ Rata -rata } & & & & & & & 3,22 \\
\hline
\end{tabular}

Adapun hasil distribusi variabel praktik kerja lapangan Unit Bisnis Center tergolong baik dengan rata-rata skor jawaban dengan nilai mean $=3,22$. Hal ini menunjukkan pelaksanaan PKL Unit Bisnis Center memiliki dampak yang cukup baik bagi peserta didik kelas XI OTKP dan Akuntasi dalam dunia kewirausahaan.

\section{Distribusi Variabel Minat Berwirausaha}

Variabel minat berwirausaha terdiri dari dua sub variabel yakni karakteristik seorang entrepreneur (wirausaha) dengan indikator: (1) berani mengambil resiko, (2) menyukai tantangan, (3) visi jauh ke depan, dan (4) kemauan untuk bekerja keras. Sub variabel kedua yaitu dukungan untuk berwirausaha dengan indikator dukungan guru, sekolah keluarga dan teman sebaya. Minat Berwirausaha terdiri dari 22 item pernyataan. Untuk mengukur indikator dapat menggunakan skala likert dengan rentang $1-4$ sesuai dengan alternatif pernyataan pada instrumen penelitian.

Adapun distribusi jawaban responden mengenai minat berwirausaha dapat dilihat pada tabel dibawah ini.

Tabel 3 Jawaban Responden Variabel Minat Berwirausaha

\begin{tabular}{|c|c|c|c|c|c|c|c|c|c|}
\hline \multirow{3}{*}{ Item } & \multicolumn{8}{|c|}{ Skor } & \multirow{3}{*}{ Rata - rata } \\
\hline & \multicolumn{2}{|c|}{4} & \multicolumn{2}{|c|}{3} & \multicolumn{2}{|c|}{2} & \multicolumn{2}{|c|}{1} & \\
\hline & f & $\%$ & f & $\%$ & f & $\%$ & f & $\%$ & \\
\hline item 27 & 80 & 37,4 & 126 & 58,9 & 8 & 3,7 & $\mathbf{0}$ & $\mathbf{0}$ & 3,34 \\
\hline item 28 & 49 & 22,9 & 152 & 71,0 & 13 & 6,1 & 0 & 0 & 3,17 \\
\hline item 29 & 69 & 32,2 & 141 & 65,9 & 4 & 1,9 & 0 & $\mathbf{0}$ & 3,30 \\
\hline item 30 & 82 & 38,3 & 122 & 57,0 & 10 & 4,7 & $\mathbf{0}$ & $\mathbf{0}$ & 3,34 \\
\hline item31 & 63 & 29,4 & 125 & 58,4 & 25 & 11,7 & 1 & 5 & 3,17 \\
\hline item 32 & 108 & 50,5 & 99 & 46,3 & 7 & 3,3 & 0 & 0 & 3,47 \\
\hline item 33 & 69 & 32,2 & 139 & 65,0 & 5 & 2,3 & 1 & 5 & 3,29 \\
\hline item 34 & 47 & 22,0 & 149 & 69,6 & 18 & 8,4 & $\mathbf{0}$ & $\mathbf{0}$ & 3,14 \\
\hline item 35 & 46 & 21,5 & 123 & 57,5 & 42 & 19,6 & 3 & 1,4 & 2,99 \\
\hline item 36 & 99 & 46,3 & 100 & 46,7 & 14 & 6,5 & 1 & 5 & 3,39 \\
\hline item37 & 90 & 42,1 & 112 & 52,3 & 12 & 5,6 & $\mathbf{0}$ & 0 & 3,36 \\
\hline item 38 & 77 & 36,0 & 131 & 61,2 & 6 & 2,8 & $\mathbf{0}$ & 0 & 3,33 \\
\hline item39 & 59 & 27,6 & 135 & 63,1 & 20 & 9,3 & $\mathbf{0}$ & $\mathbf{0}$ & 3,18 \\
\hline item40 & 89 & 41,6 & 109 & 50,9 & 16 & 7,5 & $\mathbf{0}$ & $\mathbf{0}$ & 3,34 \\
\hline item41 & 37 & 17,3 & 147 & 68,7 & 30 & 14,0 & 0 & 0 & 3,03 \\
\hline
\end{tabular}




\begin{tabular}{|c|c|c|c|c|c|c|c|c|c|}
\hline \multirow{3}{*}{ Item } & \multicolumn{8}{|c|}{ Skor } & \multirow{3}{*}{ Rata - rata } \\
\hline & \multicolumn{2}{|c|}{4} & \multicolumn{2}{|c|}{3} & \multicolumn{2}{|c|}{2} & \multicolumn{2}{|c|}{1} & \\
\hline & f & $\%$ & f & $\%$ & f & $\%$ & f & $\%$ & \\
\hline item42 & 115 & 53,7 & 94 & 43,9 & 5 & 2,3 & 0 & 0 & 3,51 \\
\hline item 43 & 45 & 21,0 & 139 & 65,0 & 30 & 14,0 & 0 & $\mathbf{0}$ & 3,07 \\
\hline item44 & 52 & 24,3 & 135 & 63,1 & 23 & 10,7 & 4 & 1,9 & 3,10 \\
\hline item45 & 13 & 6,1 & 114 & 53,3 & 81 & 37,9 & 6 & 2,8 & 2,63 \\
\hline item 46 & 25 & 11,7 & 128 & 59,8 & 56 & 26,2 & 5 & 2,3 & 2,81 \\
\hline item47 & 73 & 34,1 & 128 & 59,8 & 12 & 5,6 & 1 & 5 & 3,28 \\
\hline item 48 & 26 & 12,1 & 119 & 55,6 & 67 & 31,3 & 2 & 5 & 2,79 \\
\hline \multicolumn{2}{|c|}{ Rata -rata } & & & & & & & & 3,18 \\
\hline
\end{tabular}

Adapun hasil distribusi variabel minat berwirausaha tergolong tinggi dengan diperoleh nilai rata-rata 3,18 , sehingga distribusi frekuensi variabel minat berwirausaha tergolong tinggi. Hal ini menunjukkan bahwa siswa memiliki minat berwirausaha yang tinggi.

\section{Pengaruh Pendidikan Kewirausahaan terhadap Minat Berwirausaha}

Berdasarkan Tabel 4 dapat diketahui bahwa nilai t hitung $(6,325)>t$ tabel $(1,971)$ dengan nilai sig $=0,000<0,05$, maka Ho yang berbunyi tidak terdapat pengaruh positif dan signifikansi pendidikan kewirausahaan terhadap minat berwirausaha siswa Kelas XI jurusan OTKP dan Akuntansi SMK Negeri 2 Kediri ditolak, sedangkan Ha yang berbunyi terdapat pengaruh positif dan signifikan pendidikan kewirausahaan terhadap minat berwirausaha diterima.

\section{Pengaruh Praktik Kerja Lapang Unit Bisnis Center terhadap Minat Berwirausaha}

Berdasarkan Tabel 4 dapat diketahui bahwa nilai t hitung $(3,442)>t$ tabel $(1,971)$ dengan nilai sig $=0,001<0,05$, maka Ho yang berbunyi tidak terdapat pengaruh positif dan signifikansi praktik kerja lapangan unit bisnis center terhadap minat berwirausaha siswa Kelas XI jurusan OTKP dan Akuntansi SMK Negeri 2 Kediri ditolak, sedangkan Ha yang berbunyi terdapat pengaruh positif dan signifikan praktik kerja lapangan unit bisnis center terhadap minat berwirausaha diterima.

Tabel 4 Hasil Uji T Pendidikan Kewirausahaan dan PKL Bisnis Center terhadap Minat Berwirausaha

\begin{tabular}{lllll}
\hline Variabel bebas & T hitung & T tabel & Sig & Keterangan \\
\hline pendidikan kewirausahaan & 6,325 & 1,971 & 0,000 & $\begin{array}{l}\text { Ho ditolak } \\
\text { Ha diterima }\end{array}$ \\
PKL Bisnis Center & 3,442 & 1,971 & 0,001 & $\begin{array}{l}\text { Ho ditolak } \\
\text { Ha diterima }\end{array}$ \\
\hline
\end{tabular}

\section{Pengaruh Pendidikan Kewirausahaan dan Praktik Kerja Lapang Unit Bisnis Center terhadap Minat Berwirausaha}

Pengujian F (simultan) dilakukan untuk melihat bagaimanakah pengaruh semua variabel bebas secara bersama-sama terhadap variabel terikat, atau untuk menguji apakah model regresi yang kita buat baik/signifikan atau tidak baik/non signifikan. Penghitungan menggunakan uji Anova dengan bantuan software SPSS 18 for windows.

Berdasarkan hasil analisis penelitian diketahui bahwa f hitung sebesar 50,904 > f tabel 3,03 serta hasil signifikansi sebesar $0,000<0,05$. Maka dapat diambil kesimpulan bahwa secara simultan terdapat pengaruh positif dan signifikan pendidikan kewirausahaan dan praktik kerja lapangan unit bisnis center terhadap minat berwirausaha. 


\section{PEMBAHASAN}

\section{Deskripsi Variabel Pendidikan Kewirausahaan}

Pendidikan Kewirausahaan menurut Wulandari (2019:22) adalah usaha atau kegiatan yang terencana dan aplikatif untuk meningkatkan pengetahuan dan kompetensi peserta didik melalui ide-ide kreatif, inovatif dan berani mengambil resiko dari tindakan yang dilakukan. Pendidikan kewirausahaan merupakan upaya sekolah dalam memberikan pengetahuan mengenai dunia kewirausahaan terhadap peserta didik, baik dalam pembelajaran di Kelas maupun praktik secara langsung. Pendidikan kewirausahaan yang diterapkan di Sekolah Kejuruan (SMK) diharapkan mampu mencetak wirausahawirausaha muda.

Berdasarkah hasil distribusi frekuensi jawaban responden pada variabel pendidikan kewirausahaan rata -rata menunjukkan keseluruhan termasuk dalam kategori baik. Hal ini menunjukkan bahwa pendidikan kewirausahaan yang diajarkan di sekolah sangat mempengaruhi peserta didik untuk mengembangkan kompetensi dan potensi diri dalam dunia kewirausahaan.

\section{Deskripsi Variabel Praktik Kerja Lapangan Unit Bisnis Center}

Praktik Kerja Lapangan Unit Bisnis Center merupakan salah satu kegiatan yang dibuat oleh sekolah sebagai tempat atau peserta didik untuk praktek mengenai penjualan dan pelayanan kepada konsumen secara langsung. Kegiatan ini dilaksanakan dan diawasi langsung oleh sekolah melalui penugasan guru atau pembimbing dari Bisnis Center kepada peserta didik yang magang di Bisnis Center.

Berdasarkan dari hasil penelitian Praktik Kerja Lapangan Unit Bisnis Center yang dilakukan oleh peserta didik Kelas XI OTKP dan Akuntansi menunjukkan distribusi frekuensi variabel praktik kerja lapangan unit bisnis center tergolong baik. Hal ini menunjukkan pelaksanaan PKL unit bisnis center memiliki dampak yang cukup baik bagi peserta didik kelas XI OTKP dan Akuntansi dalam dunia kewirausahaan.

\section{Deskripsi Variabel Minat Berwirausaha}

Menurut Suryamanmin dalam Wulandari (2019:19) minat wirausaha adalah kemampuan untuk memberanikan diri dalam memenuhi kebutuhan hidup serta memecahkan permasalahan hidup guna memajukan usaha atau menciptakan usaha baru dengan kekuatan yang ada pada diri sendiri. Setiap manusia memiliki keinginan untuk memiliki sebuah usaha yang hasilnya dapat atau mampu mencukupi kebutuhan pribadinya.

Berdasarkan hasil penelitian minat berwirausaha peserta didik peserta didik Kelas XI OTKP dan Akuntansi menunjukkan rata - rata keseluruhan tergolong tinggi dapat disimpulkan bahwa minat berwirausaha memiliki kriteria tinggi. Hal ini menunjukkan bahwa peserta didik memilki keinginan untuk berwirausaha setelah lulus dari sekolah.

\section{Pengaruh Pendidikan Kewirausahaan terhadap Minat Berwirausaha}

Pendidikan kewirausahaan merupakan salah satu program antisipasi sekaligus pengentasan anak didik dari ketergantungan lapangan pekerjaan dari orang lain (Wulandari, 2019:28). Pendidikan kewirausahaan bertujuan untuk membentuk karakter dan potensi peserta didik melalui ketrampilan berwirausaha sehingga peserta didik dapat mandiri dan membentuk usaha sendiri. Menurut Wijaya (2017:34) "pendidikan kewirausahaan dapat memberikan peluang tumbuh dan berkembang potensi kreativitas dan inovasi peserta didik.

Berdasarkan hasil penelitian yang dilakukan pada analisis uji t (secara parsial) bahwa ada pengaruh yang signifikan antara pendidikan kewirausahaan terhadap minat berwirausaha peserta didik Kelas XI OTKP dan Akuntansi SMK Negeri 2 Kediri.

Hasil penelitian ini sesuai dengan hasil penelitian sebelumnya yang dilakukan oleh Rosyi (2018) bahwa pendidikan kewirausahaan berpengaruh positif dan signifikan dalam minat berwirausaha. Selanjutnya penelitian Wulandari (2019) terdapat pengaruh positif dan signifikan pendidikan kewirausahaan di sekolah terhadap minat berwirausaha melalui sikap berwirausaha. 
Pendidikan kewirausahaan diberikan di lingkungan sekolah berdasarkan tingkat kebutuhan dan penyesuaian dengan kurikulum yang berlaku di sekolah tersebut. Dari tingkat sekolah dasar, sekolah menengah sampai dengan perguruan tinggi. Salah satunya pendidikan kewirausahaan yang diberikan pada sekolah kejuruan (SMK). Pendidikan kewirausahaan yang diterapkan di Sekolah Kejuruan (SMK) diharapkan mampu mencetak wirausaha-wirausaha muda

Berdasarkan penelitian yang pernah dilakukan sebelumnya dan teori yang telah dikemukakan dengan hasil penelitian dapat disimpulkan bahwa terdapat pengaruh signifikan antara pendidikan kewirausahaan terhadap minat berwirausaha. Oleh karena itu pendidikan kewirausahaan dapat mendorong peserta didik untuk memiliki minat berwirausaha.

\section{Pengaruh Praktik Kerja Lapangan Unit Bisnis Center terhadap Minat Berwirausaha}

Menurut Pedoman Praktik Kerja Lapangan peserta didik SMK (2018:2), praktik kerja lapangan merupakan kegiatan pembelajaran yang dilakukan Dunia Usaha dan Dunia Industri (DUDI) dan atau lapangan kerja lain untuk penerapan, pemantapan, dan peningkatan kompetensi. Bisnis Center merupakan salah satu sarana yang dibuat oleh sekolah sebagai tempat atau peserta didik untuk praktik mengenai penjualan dan pelayanan kepada konsumen secara langsung.

Berdasarkan hasil penelitian yang dilakukan pada analisis uji t (secara parsial) bahwa ada pengaruh yang signifikan antara Praktik Kerja Lapangan Unit Bisnis Center terhadap minat berwirausaha peserta didik Kelas XI OTKP dan Akuntansi SMK Negeri 2 Kediri.

Hasil penelitian ini sesuai dengan penelitian sebelumnya yang dilakukan oleh Nasrudin (2014) terdapat pengaruh praktik kantin sekolah dan prakerin terhadap minat berwirausaha pada peserta didik Kelas XI Jurusan Pemasaran SMKN 1 Turen baik secara parsial maupun simultan. Selanjutnya hasil penelitian Khusnul (2015) Terdapat pengaruh positif dan signifikan antara praktik kewirausahaan terhadap minat berwirausaha siswa kelas X SMK Muhammadiyah 3 Singosari

Bisnis Center merupakan salah satu sarana yang dibuat oleh sekolah sebagai tempat atau peserta didik untuk praktek mengenai penjualan dan pelayanan kepada konsumen secara langsung. Kegiatan penjualan dan pelayanan dilakukan oleh peserta didik sendiri beserta didampingi dan diawasi oleh pembimbing (guru dan staf ahli). Sistem Bisnis Center lebih mengarah sebagai mini market berskala kecil sampai dengan menengah, barang yang dijual dan ditawarkan adalah berbagai barang kebutuhan sehari-hai (bahan pokok : sabun, beras, gula, minyak, dan lain-lain). Peserta didik diwajibkan untuk mengambil barang unit Bisnis Center kemudian dijual kembali kepada masyarakat (lingkungan sekitar). Peserta didik dapat mengambil untung dari pembelian harga barang yang lebih murah dari toko atau supermarket lainnya, untuk dijual kembali dengan menentukan sendiri harga atau tarif, namun disesuaikan dengan persayaratan dan ketentuan dari sekolah.

Berdasarkan hasil dari peneltian sebelumnya dan hasil penelitian yang dilakukan oleh peneliti dapat disimpulkan bahwa terdapat pengaruh signifikan antara Praktik Kerja Lapangan Unit Bisnis Center terhadap minat berwirausaha. Oleh karena itu Praktik Kerja Lapangan Unit Bisnis Center dapat mendorong peserta didik untuk memiliki minat berwirausaha.

\section{Pengaruh Pendidikan Kewirausahaan dan Praktik Kerja Lapangan Unit Bisnis Center terhadap Minat Berwirausaha}

Menurut Wijaya (2017:34) "pendidikan kewirausahaan dapat memberikan peluang tumbuh dan berkembang potensi kreativitas dan inovasi peserta didik. Menurut Pedoman Praktik Kerja Lapangan peserta didik SMK (2018:2), praktik kerja lapangan merupakan kegiatan pembelajaran yang dilakukan Dunia Usaha dan Dunia Industri (DUDI) dan atau lapangan kerja lain untuk penerapan, pemantapan, dan peningkatan kompetensi.

Menurut Suryamanmin dalam Wulandari (2019:19) minat wirausaha adalah kemampuan untuk memberanikan diri dalam memenuhi kebutuhan hidup serta memecahkan permasalahan hidup guna memajukan usaha atau menciptakan usaha baru dengan kekuatan yang ada pada diri sendiri. Minat berwirausaha adalah kemampuan seseorang dalam memecahkan permasalahan hidup duna mendapatkan kehidupan yang lebih baik melalui jalan berwirausaha atau menciptakan sebuah usaha. 
Hasil penelitian dari peneliti sebelumnya Rosyi (2018) terdapat pengaruh positif dan signifikan pendidikan kewirausahaan dan lingkungan keluarga. Selanjutnya hasil penelitian sebelumnya Khusnul (2015) terdapat pengaruh positif dan signifikan antara prestasi belajar dan praktik kewirausahaan secara simultan terhadap minat berwirausaha siswa kelas X SMK Muhammadiyah 3 Singosari.

Berdasarkan hasil penelitian dengan menggunakan uji hipotesis $\mathrm{f}$ (simultan) dapat dilihat adanya pengaruh pendidikan kewirausahaan dan praktik kerja lapangan unit bisnis center terhadap minat berwirausaha. Pendidikan Kewirausahaan dan Praktik Kerja Lapangan Unit Bisnis Center memiliki pengaruh sebesar $32 \%$ dilihat dari nilai R Square. Hal ini menunjukkan bahwa pendidikan kewirausahaan dan praktik kerja lapangan unit bisnis center terhadap minat berwirausaha memiliki pengaruh positif dan signifikansi sebesar $32 \%$.

Berdasarkan hasil penelitian sebelumnya dan hasil dari penelitian penulis ditemukan persamaan bahwa pendidikan kewirausahaan memiliki pengaruh yang signifikan terhadap minat berwirausaha. oleh karena itu pendidikan kewirausahaan berpengaruh dalam menumbuhkan minat berwirausaha peserta didik. Selanjutnya dari hasil penelitian yang dilakukan oleh peneliti didapatkan bahwa praktek kerja lapangan unit bisnis center memiliki pengaruh yang signifikan terhadap minat berwirausaha.

\section{SIMPULAN DAN SARAN}

\section{Simpulan}

Berdasarkan hasil penelitian dan pembahasan dapat diperoleh kesimpulan bahwa: (1) Hasil distribusi variabel ( $\mathrm{X}^{\mathrm{I}}, \mathrm{X}^{2}$ dan $\left.\mathrm{Y}\right)$ : (a) pendidikan kewirausahaan $\left(\mathrm{X}^{1}\right)$ memiliki kriteria baik, hal ini menunjukkan bahwa pendidikan kewirausahaan yang diajarkan di sekolah sangat mempengaruhi peserta didik untuk mengembangkan kompetensi dan potensi diri dalam dunia kewirausahaan; (b) variabel praktik kerja lapangan unit bisnis center $\left(\mathrm{X}^{2}\right.$ memiliki kriteria baik, Hal ini menunjukkan pelaksanaan PKL unit bisnis center memiliki dampak yang cukup baik bagi peserta didik kelas XI OTKP dan Akuntansi dalam dunia kewirausahaan; (c) variabel minat berwirausaha (Y) memiliki kriteria tinggi, dilihat dari hasil angket yang diberikan, rata - rata peserta didik menjawab dengan alternatif jawaban sangat setuju, dan setuju, hal tersebut menunjukkan bahwa peserta didik Kelas XI OTKP dan Akuntansi memiliki minat berwirausaha yang tinggi; (2) Terdapat pengaruh positif dan signifikan pendidikan kewirausahaan terhadap minat berwirausaha; (3) Terdapat pengaruh positif dan signifikan praktik kerja lapangan unit bisnis center terhadap minat berwirausaha; dan (4) Terdapat pengaruh positif dan signifikan pendidikan kewirausahaan dan praktik kerja lapangan unit bisnis center terhadap minat berwirausaha.

\section{Saran}

Penelitian ini diharapkan dapat dijadikan referensi bagi peneliti selanjutnya. Khususnya bagi peneliti yang ingin mengambil topik dan variabel yang masih berkaitan dengan minat berwirausaha. Diharapkan bagi peneliti selanjutnya dapat melakukan penelitian lebih mendalam mengenai minat berwirausaha.

\section{DAFTAR RUJUKAN}

Rosyi, A.H. 2019. Pengaruh Pendidikan Kewirausahaan dan Lingkungan Keluarga Terhadap Minat Berwirausaha (Studi Pada Siswa Jurusan Pemasaran SMK Negeri 2 Kediri). Skripsi tidak diterbitkan. Malang: Fakultas Ekonomi dan Bisnis Program Studi Pendidikan Bisnis/ Tata Niaga Universitas Negeri Malang.

Direktorat Pembinaan Sekolah Menengah Kejuruan Direktorat Jenderal Pendidikan Dasar dan Menengah. 2018. Pedoman Praktik Kerja Lapangan Peserta Didik SMK. Jakarta : Kementrian Pendidikan dan Kebudayaan Republik Indonesia.

Sugiyono. 2016. Metode Penelitian Kuantitatif, Kualitatif, dan R \& D. Bandung: Alfabeta.

Wijaya, O. 2016. Entrepreneur Bagaimana Menciptakannya?. Jakarta :PT Gramedia Pustaka Utama

Wijaya, D. 2017. Pendidikan Kewirausahaan Untuk Sekolah dan Perguruan Tinggi. Yogyakarta:Pustaka Pelajar.

Wulandari, Y. 2019. Pengaruh Pendidikan Kewirausahaan di Sekolah, Lingkungan Pertemanan, dan Lingkungan Keluarga Terhadap Minat Berwirausaha melalui Sikap Berwirausaha (Studi pada Siswa Kelas XI dan XII SMK se - Kab Malang Program Studi Administrasi Perkantoran). Tesis tidak diterbitkan, Malang: Pascasarjana Program Studi Pendidikan Bisnis dan Manajemen Universitas Negeri Malang. 